Archives of Agriculture and Environmental Science

\title{
Role of credit in maize (Zea mays L.) production and assessment of food security in a selected area of Bangladesh
}

\author{
Most. Rehana Akter ${ }^{1}$, Mohammad Ataur Rahman ${ }^{2 *}$ and Md. Rais Uddin Mian ${ }^{3}$ \\ ${ }^{1}$ Junior Officer, Bangladesh Krishi Bank, BANGLADESH \\ ${ }^{2}$ Department of Agricultural Finance, Bangladesh Agricultural University, Mymensingh -2202, BANGLADESH \\ ${ }^{3}$ Department of Agricultural Finance, Bangladesh Agricultural University, Mymensingh -2202, BANGLADESH \\ *Corresponding author's E-mail: marahman@bau.edu.bd
}

\section{ARTICLE HISTORY}

Received: 18 January 2020

Revised received: 25 February 2020

Accepted: 13 March 2020

\section{ABSTRACT}

Credit provides the means for many farmers to adjust their operations to keep up with the constant changes and, by doing so, to improve their operations. It also contributes to achieve food security of households. Tabular method is used to analyze credit profile, multiple regression analyses are used to determine the impact of credit on maize production and "Modified" OECD scale is used to measure calorie intake level of the 60 maize farming households who has got agricultural credit from Rajshahi Krishi Unnayan Bank in Lalmonirhat district of Bangladesh. Data were collected through field survey by using pre-designed and pre-tested interview schedule. TK.10500, 26333.33, 92103.77 (US\$ 125, 313.49, 1096.47) for small, medium and large categories, respectively, which was $100 \%$ of the total applied amount. The total principal received by the household was about TK. 50, 02,500 (US\$59553.57) and at 9\% interest it became TK. 54, 52,725 (US\$ 64913.39). The repayment performance of the households was about $100 \%$. It is also revealed from the study that credit had a positive impact on fertilizer demand and irrigation demand and overall a positive impact on maize production. The coefficient of maize production with respect to agricultural credit was 0.081 . The elasticity of fertilizer and irrigation demand with respect to credit was 0.016 and 0.543 respectively. The calorie intake situation of the sample households depicts that about $6.67 \%$ of the respondents belonged to the ultra-poor whose per day calorie intake was 1481.991 k.cal. About $20 \%$ of respondents were hardcore poor whose per day calorie intake was 1722.133 k.cal. The persons belonged to the absolute poor about $21.67 \%$ and per capita calorie intake was 1934.605 k.cal. The rest $51.67 \%$ belonged to the non-poor group. Different financial institutions should disburse sufficient agricultural credit to fulfill the requirement of the farmers.

(C)2020 Agriculture and Environmental Science Academy

Citation of this article: Akter, M.R., Rahman, M.A. and Mian, M.R.U. (2020). Role of credit in maize (Zea mays L.) production and assessment of food security in a selected area of Bangladesh. Archives of Agriculture and Environmental Science, 5(1): 18-24, https://dx.doi.org/10.26832/24566632.2020.050103

\section{INTRODUCRION}

Bangladesh is one of the world's most densely populated countries, with its people crammed into a delta of rivers that empty into the Bay of Bengal (BBC, 2019). Most of the people are dependent on agriculture and it is essential to diversify crops for increasing population to ensure food security. Maize is one of the most important cereal crops and it is one of the most leading crops in the world. Maize is a versatile crop and is the nutritious than rice in terms of protein, phosphorus, fat content. Among different districts of the country Dinajpur, Lalmonirhat, Rangpur, Bogra, Kushtia, Chuadanga and Dhaka are observed to be more progressive in maize cultivation. Bangladesh has 14.09 million hectares of cultivated land and it is estimated that nearly 2.8 million hectares are suitable for maize cultivation. But presently it covers only 3.5 lakh hectares and the production is 
about 23 lakh metric tons (BBS, 2016).

Credit is a catalyst in production, the increasing flow of which may result in improved per hectare productivity. Agricultural credit is also important to consumer in achieving food security. Different credit sources and institutions have geared towards the development of agriculture and achievement of food security (Okeke and Chukuemeka, 2018). Food security refers to the situation 'when all people, at all times, have physical, social and economic access to sufficient, safe and nutritious food that meets their dietary needs and food preferences for an active and healthy life' (FAO, 2011). Food security encompasses three elements: availability, accessibility and utilization (USAID, 1996). Bangladesh's high poverty and under nutrition rates are exacerbated by frequent natural disasters and high population density. The country's poverty rate is now $21.8 \%$, having fallen by $1.3 \%$ over the past year (BBS, 2018). The present rate of ultra -poor is $11.3 \%$. BBS drew up its estimated based on the 2010 household income and expenditure survey. From 2005 till the proceeding five years, poverty fell by $1.7 \%$ and $1.2 \%$ between 2010 and 2016. Now BBS estimates a similar type of poverty reduction. In the corresponding period of 2016, the ultrapoverty rate was $12.9 \%$.

According to the World Bank, Bangladesh's poverty rate fell from $82 \%$ in 1972 , to $18.5 \%$ in 2010 , to $13.8 \%$ in 2016 , and below $9 \%$ in 2018 , as measured by the percentage of people living below the international extreme poverty line. Based on the current rate of poverty reduction, Bangladesh is projected to eliminate extreme poverty by 2021, first nation in South Asia to do so.

Maize or corn (Zea mays) is a plant belonging to the family of grasses (Poaceae). It is cultivated globally being one of the most important cereal crops worldwide. In some parts of the world, maize is used as food grain for human consumption. In addition, it is used as an important feed and fodder for animals. Nearly, 500 products of maize have been listed in the USA. It is also being recently used as biofuel. Maize is an excellent crop for food, feed and industrial utilization. Vitamin A rich maize is an example that has potential in addressing micronutrient deficiencies and promoting dietary diversity among the populations. Maize is frequently used as fish feed in small scale fish farming and has been used successfully as energy sources in the diet of many carnivorous fish. Maize is relatively low production costs, along with the increasing consumption of maize flour and cornmeal where micronutrient deficiencies are common public health problems; make this food staple an ideal food vehicle for fortification (Ranum et al., 2014).

The necessity of credit for rural producers in adopting modern technology like the maize production has been realized long since. Access to credit would enable credit-demanded farmers to take advantage of the available productive opportunities and increase maize productivity (Awunyo-Vitor and Al-Hassan, 2014). Emphasis has been given too many institutions to increase more fund in agriculture. Various nationalized commercial banks, other private commercial banks, and different big or small NGOs insisted by the Government of Bangladesh (GoB) have also been to finance agriculture. Various NGOs, however, are involved providing credit to the millions of landless, marginal and small farmers in rural areas of Bangladesh. Among these, Bangladesh Krishi Bank (BKB) and Rajshahi Krishi Unnayan Bank (RAKUB) are the key institutions for providing increased amount of credit to the farmers with a view to developing agricultural sector by and large, different agro based industries, proper marketing of farm products in Bangladesh.

Maize is not only highly productive, but also nutritious crop used as a human food, feed for poultry and fodder for livestock. Maize helps in improving the nutritional status of the rural people. It also indicates that the livelihood and standard of living of the maize farmers will be improved to some extent. The specific objectives of the study are assessing the credit profile, impact of credit on maize production, the calorie intake level of the sample households.

\section{MATERIALS AND METHODS}

On the basis of higher concentration of maize production, four villages namely Nijshekhsundor, Parshekhsundor, Moddhogoddimari and Dalalpara under Hatibandha upazila of Lalmonirhat district were randomly selected for the study. The random sampling technique was applied for the selection of the sample. A total of 60 different categories of maize farmers was selected from four villages who were the beneficiaries of Rajshahi Krishi Unnayan Bank of Dowani branch. Survey method was followed to collect data from the respondents. Data were collected by the researcher herself through personal interview. The period covered in this study was July 2017 to June, 2018. Data were collected during September to October, 2018. Repeated visits were made to collect the necessary data.

\section{Analytical tools}

In order to explain the effects of different inputs on maize production, multiple linear regression function was chosen on the basis of the theoretical background (Gujarati, 2004). A general specification of the production function was considered by assuming that area under maize production, seed, fertilizers, manure and labour man days have an impact on maize production. When data were tested to check the multicollinearity problem among the independent variables and the researcher found that the variables area under maize production and labour man days significantly correlated with other variables. So the researcher removed these variables from the classical production function.

The general specification of the function was as follows (Eq. 1)

$Y=f(S, F, I, P, M, C)$

Where

$\mathrm{Y}=$ Amount of maize production $(\mathrm{kg})$

$\mathrm{S}=$ Cost of seed (Tk.)

$\mathrm{F}=$ Cost of chemical fertilizer (Tk.)

$\mathrm{I}=$ Cost of irrigation (Tk.)

$\mathrm{P}=$ Cost of pesticide (Tk.)

$\mathrm{M}=$ Amount of manure $(\mathrm{kg})$

$\mathrm{C}=$ Amount of credit (Tk.) 
As the objective is to assess the impact of credit on maize production, credit has no direct impact on maize production, but it has an impact on inputs utilization mainly on chemical fertilizer and irrigation. It was assumed that the price of fertilizer and bank credits have an impact on the amount of fertilizer used for maize cultivation and similarly, the price of irrigation and bank credits had an impact on irrigation per hectare employed.

To estimate the impact of agricultural credit on maize production the following hypothetical model had been developed (Eq. 2).

$$
Y=f(F, I)
$$

\section{Where}

$\mathrm{Y}=$ Amount of maize production $(\mathrm{kg})$

$\mathrm{F}=$ Cost of chemical fertilizer

$\mathrm{I}=$ Cost of irrigation

$$
\mathrm{F}=f(\mathrm{Fp}, \mathrm{BC})
$$

$I=f(I p, B C)$

\section{Where}

$\mathrm{Fp}=$ Price of chemical fertilizer

$\mathrm{Ip}=$ Price of irrigation water

$\mathrm{BC}=$ Bank Credit

Equation (2) gives the maize production function while equation (3) and (4) gives chemical fertilizer, and irrigation water demand function.

\section{Empirical model}

By applying the theoretical model, the empirical model was specified as (Eq. 5)

$$
Y=\alpha S^{\beta 1} F^{\beta 2} I^{\beta 3} P^{\beta 4} M^{\beta 5} C^{\beta 6} \epsilon^{u i}
$$

\section{Where}

$\mathrm{Y}=$ Amount of maize production $(\mathrm{kg})$

$\alpha=$ Constant term

$\mathrm{S}=$ Cost of seed (Tk.)

$\mathrm{F}=$ Cost of chemical fertilizer (Tk.)

$\mathrm{I}=$ Cost of irrigation (Tk.)

$\mathrm{P}=$ Cost of pesticide (Tk.)

$M=$ Amount of manure (kg.)

$\mathrm{C}=$ Amount of credit (Tk.)

$\mu \mathrm{i}=$ Error term

Taking log on both side of equation (6) we get.

$\ln Y=\ln \alpha+\beta 1 \ln S+\beta 2 \ln F+\beta 3 \ln l+\beta 4 \ln P+\beta 5 \ln M+\beta 6 \ln C+$

$\mu \mathrm{i}$

Now, the empirical model for the impact of agricultural credit on maize production is

$$
\begin{gathered}
\mathrm{F}=\alpha \quad F_{p}^{\beta 1} \quad B C^{\beta 2} \varepsilon^{u \bar{i}} \\
\text { Or, InF }=\alpha+\beta 1 \ln F p+\beta 2 \ln B C+\mu i \\
I=\alpha I_{p}^{\beta 1} B C^{\beta 2} \varepsilon^{w i \tilde{i}} \\
\text { Or, } \operatorname{lnI}=\alpha+\beta 1 \ln \operatorname{lp}+\beta 2 \ln B C+\mu i
\end{gathered}
$$

To assess the calorie intake level of the sample households, the consumption data of the households of seven days were measured by the per person per day calorie intake level, each food item which was consumed by the family members of the sample households converted through standard value of 100 gm each food item. For the calculation, "Modified" OECD scale was used, family members are defined as one adult male and one adult female is $1: 1$, the child whose age is below 5 years considered as zero and 5-10 years considered as half of an adult member.

\section{RESULTS AND DISCUSSION}

\section{Credit profile of the respondents}

Sources of credit, interest rates and purpose of the loan are very important factors, both for the lender and receiver of credit. In this study, an attempt has been made to see whether credit receipt, its interest rate and payment status have any effects on maize production. Timely loan receipt, loan adequacy, utilization patterns and proper supervision are closely related to the repayment of a loan. The borrowers generally divert the funds mostly for unproductive or consumption purposes, as they cannot avoid the subsistence need of the family particularly among lower income people resulting in unnecessary delay in loan payment and default late delivery of credit also affects to its improper use. Proper supervision must be needed to increase the higher loan repayment rate otherwise loan overdue will be increased.

\section{Sources and purpose of loan of the respondents}

The respondents are engaged in many activities, but most of them were engaged in cultivating maize crop. In that case, RAKUB provides loan for maize production to the farmers. They provided loans for different income generating activities (IGAs) rather than maize production. It was observed that RAKUB provided loans for different purposes to their beneficiaries. Respondents of the study were the beneficiaries of RAKUB, Dowanipur branch, Hatibandha. They applied for a loan for the purpose of maize production and the branch also provide loan for this purpose.

\section{Adequacy of loan received}

Table 1 shows that the adequacy of loan for the sample households. The lone receivers were categorized in three categories, small amount <Tk. 15000 (US\$ 178.57), medium amount (Tk. 15000 to Tk. 30000) (US\$178.57-357.14) and above Tk. 30000 (US\$ 357.14). Table 1 reveals that average amount applied for 
loan in small category was Tk. 10500 (US\$125) and the average amount of loan received was Tk.10500 (US\$ 125) which was $100 \%$ of the total applied amount. On the other hand, average amount applied for loan in the medium category was Tk. 26333.33 (US\$313.49), and average amount of loan received was Tk. 26333.33 (US\$ 313.49), which was $100 \%$ of the total applied amount. But Islam et al. (2018) found their research on Banana cultivation in Bangladesh that the overall average amount of loan received was $85.4 \%$ of applied amount. Average amount applied for loan in large category was Tk. 92103.77 (US\$ 1096.47) and average amount of loan received was Tk. 92103.77 (US\$ 1096.47).

\section{Repayment of the loan}

Agricultural Credit repayment is one of the challenging aspects of agricultural financing, especially in rural communities of developing countries (Ahiaba, 2018). But the repayment tendency of loan among the respondents of Dowani branch in Bangladesh was very satisfactory. They will pay the loan next year after harvesting their crop fully. They tried to pay the loan fully without any problem as they know if they pay the amount in due time and fully, they will get more loan which will help them to expand their production and get more profit. By cultivating maize production, the respondents improved their economic position. Ahiaba (2018) found in Nigeria that the farmers who repaid input credit with a part of the harvest (The Kind Farmers), performed better in repayment than those who were repaying with cash (The Cash Farmers). Table 2 shows the repayment performance of the respondents.

From the Table 2 it shows that total principal received by the household was about Tk. 50, 02,500 (US\$ 59553.57) and at 9\% interest it became Tk. 54, 52,725 (US\$ 64913.39). The households repaid the loan after harvesting their crop. That's why the repayment performance of the households was about $100 \%$.

\section{Maize production model}

The average maize production for the sampled farmers was $11261.82 \mathrm{Kg} / \mathrm{ha}$. The results of the maize production model are presented in Table 3. Maize production was assumed to be influenced by six different variables, namely seed, fertilizer, irrigation, pesticide, manure and credit. Having a log linear specification, OLS model has been applied to estimate the parameters of the variables in the production function. Generally production increases as the area under crop increases. But in this analysis, we found that area under maize production estimated model had a multicollinearity problem which affected the independent variables. That's why we omitted area under crop as independent variable.

Table 1. Adequacy of loan received (Tk.) by the respondents.

\begin{tabular}{|c|c|c|c|c|}
\hline Category & $\begin{array}{c}\text { No. of } \\
\text { Respondent }\end{array}$ & $\begin{array}{c}\text { Average amount applied } \\
\text { for loan (Tk.) }\end{array}$ & $\begin{array}{l}\text { Average amount } \\
\text { received loan (Tk.) }\end{array}$ & $\begin{array}{c}\text { Amount received in \% } \\
\text { of amount applied }\end{array}$ \\
\hline $\begin{array}{l}\text { Small amount }(<\mathrm{Tk} .15000) \\
(<\text { US\$ 178.57) }\end{array}$ & 4 & 10500 (US\$125) & 10500 (US\$125) & 100 \\
\hline $\begin{array}{l}\text { Medium amount (Tk.15000- } \\
\text { 30000) (US\$ 178.57-357.14) }\end{array}$ & 3 & $\begin{array}{c}26333.339 \\
\text { (US\$313.49) }\end{array}$ & $\begin{array}{c}26333.33 \\
\text { (US\$313.49) }\end{array}$ & 100 \\
\hline $\begin{array}{l}\text { Large amount (>Tk.30000) } \\
\text { (>US\$ 357.14) }\end{array}$ & 53 & 92103.77 (US\$1096.49) & $\begin{array}{c}92103.77 \\
\text { (US\$1096.49) }\end{array}$ & 100 \\
\hline
\end{tabular}

Note: Tk.84 =1US\$; Source: Field Survey, 2018.

Table 2. Amount (Tk.) received and paid by the respondents.

\begin{tabular}{ll}
\hline Item & Amount (Tk.)/Percentage \\
\hline Principal amount received by the respondents & $50,02,500$ (US\$ 59553.57) \\
Interest after one year (9\%) & $4,50,225$ (US\$ 5359.82) \\
Total amount & $54,52,725$ (US\$ 64913.39) \\
Repayment by the respondents & $54,52,725$ (US\$ 64913.39) \\
Repayment performance (percentage) & $100 \%$ \\
\hline
\end{tabular}

Source: Field Survey, 2018.

Table 3. Results of the multiple log linear regression function of maize production.

\begin{tabular}{lll}
\hline Variables & Coefficient & t -values \\
\hline Constant & 1.222 & 1.002 \\
Cost of Seed (Tk.) & $0.271^{* *}$ & 2.899 \\
Cost of fertilizer (Tk.) & -0.075 & -0.201 \\
Cost of irrigation (Tk.) & $-0.092^{* *}$ & -2.678 \\
Cost of pesticide (Tk.) & $0.119^{* *}$ & 2.701 \\
Amount of manure (kg.) & $0.734^{* *}$ & 2.099 \\
Amount of credit (Tk.) & $0.081^{* *}$ & 2.371 \\
$\mathrm{R}^{2}$ & 0.961 & \\
Adjusted R ${ }^{2}$ & 0.957 & \\
F & 219.539 & \\
\hline
\end{tabular}

** indicates significance at 5\% probability level; Source: Author's estimation. 


\section{Regression analysis}

On the basis of the theoretical conception, the following values of empirical model were found. The estimated coefficient and related statistics of the equation are presented in the Table 3. The fitness of the model was good as indicated by $R^{2}$. About $96 \%$ of the total variation in the dependent variable was explained by the five variables used in explaining the maize production model. The coefficient of fertilizer and irrigation are negatively related to maize production because the cost of fertilizer and irrigation are so much which increases the cost rather decreases. That's why, the coefficient becomes negative.

The arguments in fertilizer demand function are price of fertilizer and bank credit (Table 4). It was assumed that demand for fertilizer was influenced by the price of fertilizer and current year's capability to buy fertilizer was indicated by the amount of credit received and used. The coefficient of demand for fertilizer with respect to price of fertilizer was .998 and with respect to bank credit was 016 .

The irrigation demand function includes two independent variables, the price of irrigation and the bank credit. The Table 5 shows that the coefficient of bank credit and the irrigation function is 0.543 . It indicates that use of irrigation water was positively influenced by bank credit. Availability and use of credit properly enhanced the uses of irrigation water. The coefficient of irrigation demand with respect to price of irrigation and bank credit were 0.897 and 0.543 respectively. The value of $\mathrm{R}^{2}=0.596$ indicates that the fitness of the model is good.

The coefficient of fertilizer demand with respect to bank credit was 0.016 which provides an indication that if credit was increased by $10 \%$ the demand for fertilizer might increase by
$0.16 \%$. The elasticity of irrigation demand with respect to bank credit was 0.543 . It means that an increment of credit by $10 \%$ increased that demand for irrigation by $5.43 \%$. Here, the impact of maize production with respect to bank credit (BC) was 0.081 which indicates that if credit was increased by $10 \%$ the maize production would increase by $0.08 \%$. Credit affects the demand for inputs. Thus, production is affected by credit via input demand function. Abbas et al. (2015) also found that agricultural credit; maize cropped area and agricultural labour force are positively significant related to maize production. The foregoing discussion reveals that credit had a positive impact on maize production. Increasing cost of fertilizer and irrigation affected, by decreasing maize production with respect to credit.

\section{Calorie intake situation}

Calorie intake status is an important socioeconomic aspect of the sampled household. To assess the calorie intake level of the sample households, the consumption data of selected households of seven days were measured by the per person per day calorie intake level, each food item which was consumed by the family members of the sample households converted through standard value of $100 \mathrm{gm}$ each food item.

\section{Per capita calorie intake}

To measure the weekly calorie intake level of the sampled households, a structured question, including all commonly consumed food items was developed. On the basis of the amount of food taken by the respondent and their family members per capita calorie intake was measured. It was classified into the following four categories in Table 6.

Table 4. Results of the multiple log linear regression function of fertilizer demand

\begin{tabular}{lll}
\hline Variables & Coefficient & t values \\
\hline Constant & -3.275 & -22.92 \\
Price of fertilizer (Tk.) & 0.998 & 1.192 \\
Cost of bank credit (Tk.) & 0.016 & 75.892 \\
R $^{2}$ & 0.993 & \\
Adjusted R & & \\
F & 0.992 & 3848.77 \\
\hline
\end{tabular}

Source: Author's estimation.

Table 5. Results of the multiple log linear regression function of irrigation demand.

\begin{tabular}{lll}
\hline Variables & Coefficient & t values \\
\hline Constant & -5.449 & -3.263 \\
Price of irrigation (Tk.) & 0.897 & 7.61 \\
Cost of bank credit (Tk.) & 0.543 & 4.88 \\
$\mathrm{R}^{2}$ & 0.596 & \\
Adjusted R & & \\
F & 0.582 & \\
\hline
\end{tabular}

Source: Authors estimation.

Table 6. Categories of people according to calorie intake.

\begin{tabular}{ll}
\hline Category & Calorie (k.cal) \\
\hline Ultra poor & $<1600$ \\
Hardcore poor & $1600-1804$ \\
Absolute poor & $1805-2122$ \\
Non-poor & Above 2122 \\
\hline
\end{tabular}

Source: BER, 2012. 
Table 7. Percentage of calorie intake taken by the sample households.

\begin{tabular}{lll}
\hline Categories & No. of respondents & Per person per day average calorie intake (k.cal) \\
\hline Ultra-poor $<1600$ & $4(6.67)$ & 1481.991 \\
Hardcore poor (1601-1804) & $12(20)$ & 1722.133 \\
Absolute poor (1805-2122) & $13(21.67)$ & 1934.605 \\
Non-poor (Above 2122) & $31(51.67)$ & 2650.374 \\
\hline
\end{tabular}

Source: Author's calculation. Figures with parenthesis indicate percentage of total respondents.

Table 7 depicts the percentage of calorie intake with respect to amount of credit taken by the sample household. About $6.67 \%$ of the respondents belonged to the ultra-poor whose per day calorie intake was 1481.991 k.cal. About $20 \%$ of respondents were hardcore poor whose per day calorie intake was 1722.133 k.cal. The persons belonged to the absolute poor about $21.67 \%$ and per calorie intake was 1934.605 k.cal. The rest $51.67 \%$ belonged to the non-poor group. From the above discussion, it can be summarized that most of the respondents were non-poor and they were the beneficiaries of credit. Rahman et al. (2014) also found that credit has a positive impact on caloric intake of farm households in Bangladesh. Although most of the respondents are non-poor, still there are ultra-poor and hard-core poor group of $6.67 \%$ and $20 \%$ respectively. This is due to unconsciousness and lack of knowledge about nutritious items of food. Since, food security has three fundamental components and dimensions, meeting only one or two still lefts person for food insecurity position.

From the study it is found that about $48.33 \%$ of the respondents were poor who belongs to the category ultra-poor, hardcore poor and absolute poor. The reasons behind their poverty were many, such as their large family size, low income, high food consumption, education fees, health facilities, etc. Their expenditure, including food, clothing, education, health etc. was more than their income. They can't save a single penny for the future. As a result, they can't maintain food security level and became food insecure and thus belongs to poor. Moreover, their large family size also affects a lot for being poor. Because, they don't maintain family planning and birth rate increases. It is found that there was only one earning member in most of the households. As a result, he alone couldn't maintain the family expenses compared to his income. That's why; he along with his family became poor and food insecure. However, it is true that, despite having an economic growth in the country, all people cannot get benefit from growth equally due to the different standard of their capacity, intellectual ability, etc. To assist those people, the government may take special programme in this regard. Accelerating the rate of the decline in poverty can be accomplished only by reducing poverty in the rural areas. Without accelerating rural development, reduction of poverty might not possible as a whole.

\section{Conclusion}

Credit is important for the improvement of the respondents. It works like a catalyst for maize production. It affects the crop production via input demand and positively influenced by credit. The impact of maize production with respect to credit was positive. Borrowed money has been used to a greater extent for the productive purposes by the loanee farmers. Although they used the loan in productive purposes, they cannot get enough prices of the product or due to the uncertain loss of product they cannot repay their installment on time. The findings revealed that households producing maize have higher income and better food security status than those households who have not been cultivating maize in the study area.

\section{CONFLICT OF INTEREST}

The authors declare that there is no conflict of interests regarding the publication of this paper.

\section{ACKNOWLEDGEMENTS}

The first author gratefully acknowledges the Ministry of Science and Technology of the Government of People's Republic of Bangladesh for funding this research project

Open Access: This is an open access article distributed under the terms of the Creative Commons Attribution 4.0 License, which permits unrestricted use, distribution, and reproduction in any medium, provided the original author(s) if the sources are credited.

\section{REFERENCES}

Abbas Ali Chandio, A.A. Jiang Yuansheng, J. and Mansoor Ahmed Koondher, M.A. (2015) Raising maize Productivity through Agricultural Credit: A Case Study Commercial Bank in Pakistan. European Journal of Business and Management, 7(32): 159-165

Ahiaba, U.V. (2018). Agricultural credit repayment preference among rural farmers in some rural communities in Kogi State, North-Central Nigeria. American Journal of Rural Development, 7(1): 1-5.

Awunyo-Vitor, D. and Al-Hassan, R.M. (2014). Credit constraints and smallholder maize production in Ghana. International Journal of Agricultural Resources, Governance and Ecology, 10(3): 239-256.

BBC News (2019). Bangladesh Country Profile (http://www.bbc.com/), Accessed on 5 May, 2019.

BBS (2016). Bangladesh Bureau of Statistics, Statistical Year Book of Bangladesh, Ministry of Planning, Government of the People's Republic of Bangladesh, Dhaka.

BBS (2018). Bangladesh Bureau of Statistics, Statistical Year Book of Bangladesh, Ministry of Planning, Government of the People's Republic of Bangladesh, Dhaka.

BER (2012) Bangladesh Economic Review (2011), Economic Advisory Section, Department of Finance, Ministry of Finance, Government of the People's Republic of Bangladesh, Dhaka. 
FAO (2011). Food and Agricultural Organization, The United Nations. The Role of Credit in Food Production and Food Security in Bangladesh. National Food Policy Capacity Strengthening Program.

Gujarati, D.N. (2004). Basic Econometrics. Tata McGraw Hill; $4^{\text {th }}$ edition, Page: 202.

Islam, A., Rahman, M.A. and Saham, J.K. (2018). Profitability of banana cultivation under agricultural credit in Narsingdi district of Bangladesh. Journal of Fundamental and Applied Agriculture, 3(3): 525-530.

Okeke, C.C. and Chukuemeka, O.D. (2018). An assessment of availability and utilization of agricultural credit by farmers in Aguata Local Government Area of Anambra state. Journal of Science Education, NOCEN, 2: 153-159.
Rahman, M.S., Khatun, M., Rahman, M.A., Azam, M.G. and Sultana, S. (2014). Assessing the Impact of Credit on Rice Production and Food Security on Farm Households in Bangladesh. International Journal of Innovative Research and Development, 3(6): 300-308.

Ranum, P., Pẽna-Rosas, J.P. and Garcia-Casal, M.N. (2014). Global maize production, utilization, and consumption. Annals of the New York Academy of Sciences, 13(12): 105-112.

USAID. (1996). Annual Food Assistance Report (PN-ABZ-119). United State Agency for International Development, Washington, DC.

World Bank (2018) Poverty Rate Is Reducing in Bangladesh (http://www.worldbank.org/) Accessed on 4 May, 2019. 